\title{
CAUSES AND IMPACT OF PARTY ALLIANCES AND COALITIONS ON THE PARTY SYSTEM AND NATIONAL COHESION IN SOUTH AFRICA
}

\author{
Susan Booysen \\ Susan Booysen is a Professor at the Wits School of Governance, \\ University of the Witwatersrand \\ e-mail: sbooysen@icon.co.za
}

\begin{abstract}
South Africa's first decade of democracy, 1994-2004, delivered a high volume of governing and opposition alliances and coalitions in South Africa. These alliances and coalitions catalysed the party system and facilitated the consolidation of ANC power. Simultaneously, alliances in this decade triggered the main opposition party, the $D A$, which continued to dominate opposition politics numerically through Election 2014. The second decade of democracy, 2004-2014, was characterised by continued ANC dominance, yet, instead of the ANC unremittingly usurping parties, it became subject to splits. Some of the split-offs emerged to become opposition parties. Others fused into alliances with either the ANC or existing opposition parties. This article takes stock of the development during these two decades and looks ahead to budding new alliances that may thrive in conditions of lessened ANC dominance.
\end{abstract}

\section{INTRODUCTION AND EMERGING THEORY ON THE CASE OF SOUTH AFRICA}

The African National Congress (ANC) of South Africa continues to head an established dominant-party system in a parliamentary system where Parliament is characteristically weak. Parliament is subjugated to the executive, which, in turn, is fused with and subject to the executive of the party-movement. In many respects the South African system resembles a presidential system, one in which the opposition political parties struggle continuously to assert themselves in the context of an ANC that operates in a gradually decaying yet still close-tohegemonic system. 
The ANC's continuous strength in the electoral stakes is at least partly explained by its simultaneous operation as a political party and a movement (Booysen 2011). Both organisationally and ideologically the ANC projects itself as an ongoing 'revolutionary' movement, which operates in Parliament but thrives on its direct relationship with the people of South Africa (see Booysen 2011, chapters 1 and 4).This dominant narrative, however, is not sheltered from ongoing modest and persistent changes in electoral sentiment and the strategies of political elites. The knowledge of such change encourages political parties, along with some civil society organisations aspiring to affect politics, to champion issues and possibly align with opposition parties with a view to fostering new electoral alliances.

This analysis of inter-party alliances and coalitions, as they organise at the time of elections and with an eye on the next round of elections, thus tells a story of piecemeal and gradually emerging change in party politics in South Africa.

In the main, and in line with Kadima's (2006) conceptualisations, the term 'alliance' in this article is understood as the coming together of at least two political parties prior to an election in order to maximise their votes. Hence it refers to preelection alliances or electoral pacts. 'Coalition' refers to the association of at least two political parties, working together in Parliament and/ or government on the basis of election outcomes. In this context, this term is understood to be a 'postelection coalition'. In addition, and given the continuous stream of inter-party activities in party politics and government to affect further ANC consolidation of power or generate opposition momentum, the article also notes the range of between-election and government-based forms of party cooperation which help prepare for future electoral alliances and possible post-election coalitions.

Given the ANC's large majority and the operation of the electoral system of proportional representation (PR), opposition political parties have generally been relatively disinclined to form coalitions. In conditions of incumbent dominance, combined with the PR system, post-electoral alliances between opposition parties do not leverage changes in who governs. In contrast, and at municipal level, where balances of power are often close (and where there is a 50-50 mix of PR and firstpast-the-post-FPTP - electoral systems) alliance and coalition formation is more frequent (see Booysen 2012). Such alliances mostly prevail in local municipalities with small numbers of councillors. At the time of Election 2014, when opposition parties in Gauteng province had hoped to push the ANC below the 50\% mark, there was a sudden flurry of coalition talk.

Essential to an understanding of alliances and coalitions in South African politics is the phenomenon that the ANC itself operates in an alliance - the 'Tripartite' Alliance with the Congress of South African Trade Unions (Cosatu) and the South African Communist Party (SACP) (there is also a minor civil society 
fourth member, the South African National Civic Organisation). The alliance is designed and used to help the ANC retain its hold on state power at election time.

Many of the important political and policy debates that would otherwise have informed election campaigns and opposition politics (Booysen 2010) have been conducted in the alliance. ${ }^{1}$ It helps the ANC that many of the conflicts are not driven into the domain of inter-party and electoral contests. The strength of this alliance, however, has fluctuated. By 2014 there were signs of decay. Intraalliance political debate had become more controlled and conformity and loyalty to the dominant $\mathrm{ANC}$ faction were often afforded higher value than cutting-edge debate. There were attempts by the ANC to contain a Cosatu split, which would inevitably also have an impact on the future of the ANC's electoral dominance. ${ }^{2}$ The SACP was well merged into the ANC and believed that it set the tone for much of the government's action.

As Kadima (2006, p 22) observes, largely with regard to the country's first decade of democracy, there has been a high volume of governing and opposition alliances and coalitions in South Africa, despite the fact that the ANC had established this dominant presence nationally and in most provinces. The current analysis argues that in the second decade of democracy and in conditions of continuous ANC dominance there has been a decline in alliances of major political significance in comparison with the first decade.

These initiatives appear to have positioned South Africa as an emerging two-party, within a one-party dominant system. The Democratic Alliance (DA) grew consistently in the three elections from 2004 to 2014, albeit with 2014 support remaining at the level of its 2011 local election result. It was also mainly the DA that continuously strategised to draw minor opposition parties into its camp and build this hitherto modest second leg of the two-party system. However, the Economic Freedom Fighters (EFF) - split-off from the ANC and 2014's main new entrant into electoral politics - posed a potential challenge to such a two-party configuration. The EFF was positioning itself as the centre of a budding left-opposition to the ANC, which could rise to displace the ANC (EFF 2014).

In the interim, alliance formation activities centred on small opposition

1 The main fora are occasional intra-alliance summit meetings and ANC structures and meetings in which Cosatu and the SACP are represented directly in terms of delegate status, or indirectly courtesy of dual or triple cross-cutting memberships among the three main alliance formations. These meetings include the five-yearly national ANC policy and elective conferences, the ANC's mid-term national general council (NGC) meetings, and the quarterly meetings of the ANC's national executive committee (NEC) and more regular meetings of its national working committee (NWC).

2 At the time of writing the National Union of Metalworkers of South Africa (Numsa) was threatening to split from Cosatu. ANC secretary-general Gwede Mantashe warned that the price of driving out Numsa and the suspended Cosatu general secretary, Zwelinzima Vavi, would be a toll that might not be worth paying (Munusamy 2013). ANC interventions on the eve of Election 2014 subdued Numsa's anti-ANC campaigning. 
initiatives, often with the DA as the focal point. The 2013 emergence of Agang SA, for example, followed the DA's failure to pull off a joint initiative with Agang's founder (see Joubert 2013). A 2014 DA-Agang SA alliance attempt followed and floundered. Agang SA barely made it into Parliament.

It thus appears that, as this contested evolution towards a two-party system - although on a jagged, piecemeal curve - took place, alliance formation on the grander scale of the first decade eased. The ANC remained dominant (on a reduced scale), the DA grew consistently (albeit with uncertainty as to whether it would, in due course, effectively breach the racial ceiling) ${ }^{3}$ and the EFF pursued a left-opposition alliance. There was a sense of stabilisation (see Sitter 2002) in that the ANC remained dominant amid opposition party initiatives that built up and floundered again, at least up to 2014.

The first decade of democracy and its impactful alliances are illuminated in the context of floor crossing, which catalysed the development of South Africa's party system (Booysen 2006). The floor-crossing era prevailed roughly from 2003 to 2007, with much tapering off from 2005 onwards. It was only in 2009 that South Africa's president finally signed legislation to outlaw the phenomenon (see Booysen 2011, chapter 7).

\section{Table 1}

\section{Typology of party alliances and coalitions in South Africa}

\begin{tabular}{|l|l|l|}
\hline Type of formation & Objective or effect & Illustrations \\
\hline $\begin{array}{l}\text { ALLIANCES } \\
\text { and cooperative formations that may lead to formal pre-electoral alliances }\end{array}$ \\
\hline $\begin{array}{l}\text { Formal inter-party } \\
\text { alliances - with } \\
\text { electoral participation } \\
\text { and potential } \\
\text { representation in } \\
\text { Parliament }\end{array}$ & $\begin{array}{l}\text { Consolidate power, rescue } \\
\text { dying parties, consolidate } \\
\text { cultural identities }\end{array}$ & $\begin{array}{l}\text { ANC and NNP into ANC } \\
\text { NNP and DP into DA } \\
\text { DA and ID into DA }\end{array}$ \\
\hline $\begin{array}{l}\text { Sub-party alliances } \\
\text { - channelling } \\
\text { participation and } \\
\text { representation through } \\
\text { the mother party }\end{array}$ & $\begin{array}{l}\text { Historical alliances, channel } \\
\text { contestation away from } \\
\text { issues out of party contests }\end{array}$ & $\begin{array}{l}\text { ANC's Tripartite Alliance, } \\
\text { 'governing' alliance, with } \\
\text { SACP and Cosatu, SACP } \\
\text { formally in government, but } \\
\text { over time subsumed into ANC } \\
\text { processes }\end{array}$ \\
\hline
\end{tabular}

3 The DA in Election 2014 continued to capture some black-African support, yet research showed that it was still not accepted as a non-racial party that citizens trusted to act in the interest of the bulk of black-African South Africans (see Booysen 2013b; 2014a). 


\begin{tabular}{|c|c|c|}
\hline $\begin{array}{l}\text { Occasional inter-party } \\
\text { cooperation - on issues } \\
\text { and campaigns }\end{array}$ & $\begin{array}{l}\text { Restrain governing party, } \\
\text { withhold strategic majorities } \\
\text { through cooperation } \\
\text { agreements }\end{array}$ & $\begin{array}{l}\text { DA, Cope and UDM } \\
\text { Collective for Democracy } \\
\text { EFF, Sopa and BCP }\end{array}$ \\
\hline \multicolumn{3}{|c|}{$\begin{array}{l}\text { COALITIONS } \\
\text { Inclusive of co-option to help sustain ANC power in government, or gradually help forge } \\
\text { mergers }\end{array}$} \\
\hline $\begin{array}{l}\text { Governing coalitions - } \\
\text { multiparty }\end{array}$ & $\begin{array}{l}\text { Provincial and local } \\
\text { government level, in absence } \\
\text { of outright majorities }\end{array}$ & $\begin{array}{l}\text { ANC, NP and IFP in GNU } 1994 \\
\text { ANC and NNP in Western Cape } \\
\text { ANC and IFP in KwaZulu-Natal } \\
\text { Range of municipalities with } \\
\text { diverse actors, eg, ANC and } \\
\text { NFP }\end{array}$ \\
\hline Sub-party coalitions & $\begin{array}{l}\text { Generate hegemony, focus } \\
\text { power }\end{array}$ & $\begin{array}{l}\text { ANC's Tripartite Alliance } \\
\text { through ANC and SACP } \\
\text { (Cosatu members at first did } \\
\text { not take up formal positions in } \\
\text { government) }\end{array}$ \\
\hline $\begin{array}{l}\text { De facto minority party } \\
\text { into government }\end{array}$ & $\begin{array}{l}\text { Co-option into government } \\
\text { and minor engagement of } \\
\text { individuals in government, } \\
\text { legitimating ANC and } \\
\text { moderating oppositional } \\
\text { impacts }\end{array}$ & $\begin{array}{l}\text { Mosibudi Mangena (Azapo) as } \\
\text { Cabinet member } \\
\text { Mangosuthu Buthelezi (IFP as } \\
\text { Deputy President) } \\
\text { Pieter Mulder (FF+) as Deputy } \\
\text { Minister } \\
\text { Gavin Woods (IFP) as Scopa } \\
\text { chairperson } \\
\text { Themba Godi (APC) as Scopa } \\
\text { chairperson }\end{array}$ \\
\hline
\end{tabular}

Source: Author's conceptualisation and classification.

Abbreviations: NNP - New National Party, DP - Democratic Party, EFF - Economic Freedom Fighters, ID - Independent Democrats, Cope - Congress of the People, UDM - United Democratic Movement, Sopa - Socialist Party of Azania, BCP - Black Consciousness Party, NP - National Party, IFP - Inkatha Freedom Party, GNU - Government of National Unity, NFP - National Freedom Party, Azapo - Azanian People's Organisation, FF+ - Freedom Front Plus, APC - African Peoples Convention, Scopa - Standing Committee on Public Accounts

Beyond the actions of the main parties small and micro-parties often generously embrace multipartyism and revel in minor achievements (Booysen 2011, chapter 6) such as surviving by gaining a minimal number of seats in Parliament or the provincial legislatures. They often celebrate the mere fact that they emerge from national elections with $0.25 \%$ of the vote, thereby being guaranteed one parliamentary representative. The South African closed list PR electoral system does not have thresholds beyond the requirement to win the necessary quota of 
votes to qualify for at least one representative. Several parties on both the left and the right of the political spectrum which have failed to grow electorally have turned to alliance formation. The survivalist initiatives between the Azanian People's Organisation (Azapo) and the Socialist Party of Azania (Sopa), on the left, and the Freedom Front (FF), Conservative Party (CP) and Afrikaner Unity Movement (AUM) on the right to form the FF Plus illustrate the point.

The modest convergence of other minor opposition parties around the DA took place as the ANC continued on its track of shedding support through the national and provincial elections of May 2014. The three-year-long battle of the ANC mother body against its youth leader, Julius Malema, and the 2013 establishment of the EFF, illustrated the trend to date of the DA gradually accumulating support amid multiple efforts to get challenges to the DA going. Previous ANC support losses through split-offs happened through the United Democratic Movement (UDM), which emerged from the initial National Consultative Forum of 1997/8), and the Congress of the People (Cope, in 2008/09).

The ANC's shedding trend did not constitute a rapid decline, although its serial four percentage point losses from Elections 2004 to 2009, to 2014 were substantial. The ANC compensated for losses through, for example, the return of some Cope supporters and its encroachment on the Inkatha Freedom Party (IFP) base in KwaZulu-Natal, at least until the 2011 local elections (Booysen 2011) when the split-off from the IFP, the National Freedom Party (NFP) usurped support that had become available to the ANC. ANC growth in KwaZulu-Natal continued in 2014, albeit at a moderated pace.

The DA's emergence as the main opposition party was modestly aided by an alliance with the Independent Democrats, a split-off from the Pan Africanist Congress (PAC) with a 'coloured' cultural bias. In 2004 the ID had been regarded as the electoral wunderkind, but its support had declined and the alliance saved it from electoral humiliation and facilitated DA power in the Western Cape and the Cape Town municipality. The IFP never again won the $10 \%$ of national electoral support it had received in 1994, leaving the DP-DA to become the preeminent national opposition party.

Hence, although party political alliances in South Africa beyond the 1994 unity government (dominated by the ANC) have not dramatically redirected politics, alliance formation, usurpation of minor parties by bigger ones and cooperation between parties are regular features of party politics of the second decade of democracy. Table 1 illustrates the configurations of alliances and coalitions that continuously contest the balance of power between the parties.

The wide reach of such alliances and coalitions also emerges from the fact that of the 19 parties that have won a seat or seats in South Africa's four national elections from 1994 to 2014 (see Table 2) only four - all minor in terms of electoral 
support - were not involved in some form of alliance or coalition at national or provincial level. These were the PAC, a former liberation movement, which failed to make a successful transition to multiparty democracy and suffered splits, rather than growth, with minor alliance actions at municipal level; the African Christian Democratic Party (ACDP), a national but minimally represented party); the United Christian Democratic Party (UCDP), a party in the North West province that lived on minimally beyond its Boputhatswana Bantustan origins, and the African Independent Congress (AIC), a cross-provincial-border 'protest party' in the Eastern Cape. By late 2013 the UCDP was one of the parties involved in a pre-election alliance, the Collective for Democracy, to try to 'stop the ANC from winning a two-thirds majority' in 2014 (see Seale 2013). The UCDP failed to win representation in Election 2014. All the rest of the parties have been involved in alliance-coalition arrangements either with fellow opposition parties or with the governing party.

\section{REVIEW OF PARTY ALLIANCES AND COALITIONS IN SOUTH AFRICA}

This section takes stock of the series of alliances and sprinkling of coalitions that evolved in party politics in South Africa from 1994 until the present (see Table 1). In order to capture the range of activities that characterise party political movement the analysis extends beyond the immediate pre- and post-election periods to include relevant alliance events in the periods between elections. The trends are thematically interpreted in the two subsequent sections, dealing with the analysis of the causes and consequences of the alliances and coalitions. Pivotal political events drove party political dynamics and often triggered party political developments, interpreted as secondary events and developments. The primary political events occurred in the main in the first decade of democratic South Africa.

The main events were, firstly, the unbanning of various political parties and organisations in February 1990, among them the ANC, SACP, PAC and Black Consciousness Movement (BCM). This helped to set the ball rolling for the constitutional negotiations of 1991-93 and the first democratic election, in April 1994. The PR electoral system helped confirm the ANC as the dominant party in Parliament, a dominance that peaked in 2004.

A grand alliance of formerly hostile party political and liberation movement forces rang in the new South Africa in 1993-94. The interim Constitution of 1993 provided for this Government of National Unity (GNU), consisting of the ANC, the National Party (NP) and the IFP. The alliance component of the foundational grand coalition was omitted from the final Constitution of 1996.

The GNU alliance faded with the assimilation of the NP/NNP into the ANC and the decline of the IFP into one of many small opposition parties. Whereas the 
1996 Constitution did not repeat the inclusive government provisions, there were goodwill-based possibilities for their continuation (see Table 1), albeit strictly on the ANC's terms. Meanwhile the NP and its followers became restless, resenting their secondary position in government in relation to the ANC. Torn between its roles of junior government partner and opposition party, the NP started selfimploding, a process driven by internal leadership contests and differences over strategic positioning. The NP withdrew from the GNU and tried to reinvent itself as the New National Party (NNP) but this did not halt its decline (see SchulzHerzenberg 2005). During the ensuing leadership battles the transition leader and one of the two GNU deputy presidents, FW de Klerk, left politics.

Table 2

The history of party political performance in South Africa

Results for all parties that gained representation in elections from 1994-2014

\begin{tabular}{|c|c|c|c|c|c|}
\hline & 1994 & 1999 & 2004 & 2009 & 2014 \\
\hline Party & \multicolumn{5}{|c|}{ In each of the five columns: Vote percentage $(\%)$ / No. of seats / No. of votes } \\
\hline ANC & $\begin{array}{l}62.65 \\
252 \\
12237655\end{array}$ & $\begin{array}{l}66.35 \\
266 \\
10601330\end{array}$ & $\begin{array}{l}69.69 \\
279 \\
10880915\end{array}$ & $\begin{array}{l}65.90 \\
264 \\
11650648\end{array}$ & $\begin{array}{l}65.12 \\
249 \\
11436921\end{array}$ \\
\hline DP / DA & $\begin{array}{l}1.73 \\
7 \\
338426\end{array}$ & $\begin{array}{l}9.56 \\
38 \\
1527337\end{array}$ & $\begin{array}{l}12.37 \\
50 \\
1931201\end{array}$ & $\begin{array}{l}16.66 \\
67 \\
2945829\end{array}$ & $\begin{array}{l}22.23 \\
89 \\
4091584\end{array}$ \\
\hline EFF & - & - & - & - & $\begin{array}{l}6.35 \\
25 \\
1169259\end{array}$ \\
\hline COPE & - & - & - & $\begin{array}{l}7.42 \\
30 \\
1311027\end{array}$ & $\begin{array}{l}0.67 \\
3 \\
441854\end{array}$ \\
\hline IFP & $\begin{array}{l}10.54 \\
43 \\
2058294\end{array}$ & $\begin{array}{l}8.58 \\
34 \\
1371477\end{array}$ & $\begin{array}{l}6.97 \\
28 \\
1088664\end{array}$ & $\begin{array}{l}4.55 \\
18 \\
804260\end{array}$ & $\begin{array}{l}2.40 \\
10 \\
441854\end{array}$ \\
\hline ID & - & - & $\begin{array}{l}1.73 \\
7 \\
269765\end{array}$ & $\begin{array}{l}0.92 \\
4 \\
162915\end{array}$ & - \\
\hline UDM & - & $\begin{array}{l}3.42 \\
14 \\
546790\end{array}$ & $\begin{array}{l}2.28 \\
9 \\
355717\end{array}$ & $\begin{array}{l}0.85 \\
4 \\
149680\end{array}$ & $\begin{array}{l}1 \\
4 \\
184636\end{array}$ \\
\hline FF / FF+ & $\begin{array}{l}2.17 \\
9 \\
424555\end{array}$ & $\begin{array}{l}0.80 \\
3 \\
127217\end{array}$ & $\begin{array}{l}0.89 \\
4 \\
139465\end{array}$ & $\begin{array}{l}0.84 \\
4 \\
146796\end{array}$ & $\begin{array}{l}0.9 \\
3 \\
104039\end{array}$ \\
\hline ACDP & $\begin{array}{l}0.45 \\
2 \\
88104\end{array}$ & $\begin{array}{l}1.43 \\
6 \\
228975\end{array}$ & $\begin{array}{l}1.60 \\
7 \\
250272\end{array}$ & $\begin{array}{l}0.81 \\
3 \\
142658\end{array}$ & $\begin{array}{l}0.57 \\
3 \\
104039\end{array}$ \\
\hline
\end{tabular}




\begin{tabular}{|c|c|c|c|c|c|}
\hline & 1994 & 1999 & 2004 & 2009 & 2014 \\
\hline UCDP & - & $\begin{array}{l}0.785 \\
3 \\
125280\end{array}$ & $\begin{array}{l}0.75 \\
3 \\
117792\end{array}$ & $\begin{array}{l}0.37 \\
2 \\
66086\end{array}$ & $\begin{array}{l}0.12 \\
0 \\
21744\end{array}$ \\
\hline PAC & $\begin{array}{l}1.25 \\
5 \\
243478\end{array}$ & $\begin{array}{l}0.71 \\
3 / 113125\end{array}$ & $\begin{array}{l}0.73 / 3 / 113 \\
512\end{array}$ & $\begin{array}{l}0.27 / 1 / 48 \\
530\end{array}$ & $\begin{array}{l}0.21 / 1 / 37 \\
784\end{array}$ \\
\hline MF & $\begin{array}{l}0.07 \\
0 \\
13433\end{array}$ & $\begin{array}{l}0.30 \\
1 \\
48277\end{array}$ & $\begin{array}{l}0.35 \\
2 \\
55267\end{array}$ & $\begin{array}{l}0.25 \\
1 \\
43474\end{array}$ & $\begin{array}{l}0.12 \\
0 \\
22689\end{array}$ \\
\hline Azapo & - & $\begin{array}{l}0.17 \\
1 \\
27257\end{array}$ & $\begin{array}{l}0.25 \\
1 \\
39116\end{array}$ & $\begin{array}{l}0.22 \\
1 \\
38245\end{array}$ & $\begin{array}{l}0.11 \\
0 \\
20421\end{array}$ \\
\hline APC & - & - & - & $\begin{array}{l}0.20 \\
1 \\
35867\end{array}$ & $\begin{array}{l}0.17 \\
1 \\
30676\end{array}$ \\
\hline NP / NNP & $\begin{array}{l}20.39 \\
82 \\
3983690\end{array}$ & $\begin{array}{l}6.87 \\
28 \\
1098215\end{array}$ & $\begin{array}{l}1.65 \\
7 \\
257824\end{array}$ & - & - \\
\hline FA & - & $\begin{array}{l}0.54 \\
2 \\
86704\end{array}$ & - & - & - \\
\hline AUM & - & $\begin{array}{l}0.29 \\
1 \\
46 \quad 292\end{array}$ & - & - & - \\
\hline AIC & - & - & - & - & $\begin{array}{l}0.53 \\
3 \\
97642\end{array}$ \\
\hline $\begin{array}{l}\text { Agang } \\
\text { SA }\end{array}$ & - & - & - & - & $\begin{array}{l}0.28 \\
2 \\
52350 \\
\end{array}$ \\
\hline $\begin{array}{l}\text { TOTAL } \\
\text { valid } \\
\text { votes }\end{array}$ & $\begin{array}{l}100 \\
400 \\
19533498\end{array}$ & $\begin{array}{l}100 \\
400 \\
15977142\end{array}$ & $\begin{array}{l}100 \\
400 \\
15612671\end{array}$ & $\begin{array}{l}100 \\
400 \\
17680729\end{array}$ & $\begin{array}{l}100 \\
400 \\
18402497\end{array}$ \\
\hline
\end{tabular}

Source: Compiled by author, based on IEC data of 1994, 1999, 2004, 2009 and 2014

Abbreviations: ANC - African National Congress; DP / DA - Democratic Party / Alliance; EFF - Economic Freedom Fighters; Cope - Congress of the People; IFP - Inkatha Freedom Party; ID - Independent Democrats; UDM - United Democratic Movement; FF/FF+ - Freedom Front/Plus; ACDP - African Christian Democratic Party; UCDP - United Christian Democratic Party; PAC - Pan Africanist Congress; MF - Minority Front; Azapo - Azanian People's Organisation; APC - African People's Convention; N/NP - New / National Party; FA - Federal Alliance; AUM - Afrikaner Unity Movement; AIC - African Independent Congress 
The dissolution of the NP/NNP commenced with some leaders, such as constitutional negotiator Roelf Meyer, splitting to join forces in an alliance with General Bantu Holomisa, a former Bantustan leader who had been expelled by the ANC. The IFP remained in the GNU until 2004, with its leader, Mangosuthu Buthelezi, remaining a deputy president of South Africa until 1999, when then President Thabo Mbeki appointed the ANC's Jacob Zuma to this post.

Until 2004 the ANC's rise was aided by its alliance with the NNP. This alliance did not bring in large numbers (most NNP supporters had already migrated to the DA), but there was great symbolic significance in the ANC's usurpation of its former nemesis. The results of the first five national elections show a gradual decline in the ANC's dominance from the high of its $69.69 \%$ of the national vote in 2004. In 2009 the ANC fell back to just under the two-thirds majority mark (Table 2, to $66 \%$ ) and in 2014 nationally it slipped to $62 \%$. There was thus increasing, although continuously limited space, for opposition party initiatives.

Inter-opposition party alliances in democratic South Africa vary in scope and vacillate in endurance. Most of these alliances form among minor parties but even at this level the alliances are often asymmetrical. Because joint opposition party action offers no singular benefits unless the alliance constitutes a legislative majority, the smaller parties have tended to opt for loose cooperative agreements that bring functional cooperation rather than formalised mergers. In cases where the cooperative partners are more equal, intractable negotiations often result. The relationship between Azapo and Sopa is a case in point - they split in the 1990s and by 2013 they were hoping for and then failed to achieve a merger again (see Mabasa 2013; Ndaba, 2013).

Floor crossing was introduced into the parliamentary system in 2003, largely with a view to unblocking stalemates in the evolution of the party system. It started playing a role when cracks appeared in the NP. The NNP in 2000 aligned with the then Democratic Party (DP) and the small Federal Alliance (FA) to form the DA, which governed the Western Cape for a short period. It was an unhappy union and, seeing an opportunity to split the unstable new DA, the ANC aligned with segments of the NNP to oust the DA from power in the Western Cape. The ANC-NNP coalition governed briefly until the 2004 election, when the DA won the majority, bolstered by the bulk of former supporters of the dying NNP. Floor crossing played a substantial role in party political realignment, but was terminated in 2009 (see above).

These first-decade alliances helped shape the evolving party system in South Africa. Further and relatively modest events with a political impact emerged in the form of splits from the bigger parties. The new and small parties - the UDM of 1999, the ID of 2004 and Cope of 2009 - hardly ever sustained their initial and one-election fervour. 
Table 3

\section{Range of alliance and coalition activities of parties with parliamentary representation}

\begin{tabular}{|c|c|c|}
\hline Party* & Date / period & Nature of agreement \\
\hline \multirow[t]{5}{*}{ ANC } & 1994 & $\begin{array}{l}\text { Dominant party coalition government with NP and } \\
\text { IFP }\end{array}$ \\
\hline & 2001 & $\begin{array}{l}\text { Collaborative agreement and phased coalition with } \\
\text { NNP; parties become merged }\end{array}$ \\
\hline & $2001 / 2$ & $\begin{array}{l}\text { Cooperative arrangement with the NNP, } \\
\text { specifically in the Western Cape province }\end{array}$ \\
\hline & 1994-2009 & $\begin{array}{l}\text { Coalition government with the IFP in KwaZulu- } \\
\text { Natal (mostly under IFP majority, although } \\
\text { shrinking) lets the ANC to hold executive positions } \\
\text { in the IFP-led provincial government, and from } \\
\text { 2004-09 in situation of ANC majority; MF also } \\
\text { enters the relationship }\end{array}$ \\
\hline & 2011 & $\begin{array}{l}\text { ANC and NFP form coalition governments in } \\
\text { several KwaZulu-Natal hung municipalities }\end{array}$ \\
\hline \multirow[t]{4}{*}{ DP / DA } & 2000 & $\begin{array}{l}\text { DP merges with the NNP to constitute coalition } \\
\text { style majority provincial government }\end{array}$ \\
\hline & 2003-2004 & Coalition for Change with the IFP \\
\hline & 2011 & $\begin{array}{l}\text { DA in phased coalition, growing cooperation with } \\
\text { ID, moving towards unity }\end{array}$ \\
\hline & 2014 & $\begin{array}{l}\text { DA in failed coalition-merger initiative with Agang } \\
\text { SA }\end{array}$ \\
\hline EFF & 2014 & $\begin{array}{l}\text { Includes representatives of the BCP and Sopa in its } \\
\text { candidate list, cooperates with Azapo and the PAC, } \\
\text { holds out prospects for future cooperation with } \\
\text { trade union Numsa's (envisaged) United Front }\end{array}$ \\
\hline COPE & 2009 onward & $\begin{array}{l}\text { Informal cooperation with DA, UDM; ineffectual } \\
\text { due to Cope factional wars and implosion in } \\
\text { Election } 2014 \text { (its members largely migrated back to } \\
\text { the ANC and DA) }\end{array}$ \\
\hline \multirow[t]{5}{*}{ IFP } & 1994 & $\begin{array}{l}\text { Minority party in coalition style GNU with the } \\
\text { ANC and NP }\end{array}$ \\
\hline & 1994-1999 & $\begin{array}{l}\text { Coalition style cooperation through filling one of } \\
\text { two deputy presidencies of South Africa }\end{array}$ \\
\hline & 1994-2004 & $\begin{array}{l}\text { Coalition government with the ANC in KwaZulu- } \\
\text { Natal (under IFP majority) }\end{array}$ \\
\hline & 2003-2004 & Coalition for Change with the DA \\
\hline & 2004-2009 & $\begin{array}{l}\text { Coalition government with the ANC in KwaZulu- } \\
\text { Natal (under ANC majority) }\end{array}$ \\
\hline
\end{tabular}




\begin{tabular}{|c|c|c|}
\hline ID & 2011 & $\begin{array}{l}\text { Floor-crossing party of } 2003 \text { starts cooperation with } \\
\text { DA, enters into phased merger, does not contest the } \\
2014 \text { election }\end{array}$ \\
\hline \multirow[t]{2}{*}{ UDM } & 1999 & $\begin{array}{l}\text { Original formation platform an alliance with mini- } \\
\text { NNP breakaway group under Roelf Meyer }\end{array}$ \\
\hline & 2009 on & $\begin{array}{l}\text { Informal cooperation agreement with several } \\
\text { opposition parties }\end{array}$ \\
\hline \multirow[t]{2}{*}{ FF / FF+ } & 2003 & $\begin{array}{l}\text { Coalition-merger with the Conservative Party } \\
\text { (CP, which never gained parliamentary seats), } \\
\text { the Afrikaner Unity Movement and later also the } \\
\text { Federal Alliance }\end{array}$ \\
\hline & 2009 onward & $\begin{array}{l}\text { Coalition style cooperation with ANC government } \\
\text { in deputy-ministerial executive position }\end{array}$ \\
\hline ACDP & 1994-2014 & No alliance and coalition activities on record \\
\hline UCDP & 1994-2014 & No alliance and coalition activities on record \\
\hline PAC & 1994-2014 & $\begin{array}{l}\text { No formal alliance and coalition activities on } \\
\text { record, although considered cooperating with the } \\
\text { EFF in } 2014\end{array}$ \\
\hline MF & 1999-2004 & $\begin{array}{l}\text { Coalition-style offer of its one parliamentary seat to } \\
\text { push the ANC into a two-thirds majority; MF also } \\
\text { joins the ANC's } 2004 \text { coalition with the IFP }\end{array}$ \\
\hline Azapo & $\begin{array}{l}\text { 2013-14 (and } \\
\text { earlier) }\end{array}$ & $\begin{array}{l}\text { Efforts to form an alliance, perhaps merge, with } \\
\text { split-off Socialist Party of Azania (Sopa), informal } \\
\text { cooperation with the EFF }\end{array}$ \\
\hline APC & 2008-2014 & $\begin{array}{l}\text { Split off the PAC in 2007, coalition style cooperation } \\
\text { with the ANC, in occupying chairpersonship of } \\
\text { the parliamentary Standing Committee on Public } \\
\text { Accounts (Scopa) }\end{array}$ \\
\hline \multirow[t]{4}{*}{ NP / NNP } & 1994 & $\begin{array}{l}\text { Minority party in coalition style GNU with the } \\
\text { ANC and IFP }\end{array}$ \\
\hline & 1994-1996 & $\begin{array}{l}\text { Coalition style cooperation through occupation of } \\
\text { deputy presidency of South Africa }\end{array}$ \\
\hline & 2000 & $\begin{array}{l}\text { NNP merges with DP as DA to constitute coalition } \\
\text { style majority provincial government in the } \\
\text { Western Cape }\end{array}$ \\
\hline & 2001-2004 & $\begin{array}{l}\text { Various coalitions with ANC, resulting in being } \\
\text { subsumed into the ANC }\end{array}$ \\
\hline FA & 2000 & Merges into the DA, along with the DP and NNP \\
\hline AUM & 2003 & Merger with FF and $\mathrm{CP}$ to form the FF+ \\
\hline AIC & 2006-14 & No alliance and coalition activities on record \\
\hline
\end{tabular}

*Parties are listed in the order in which they appear in Table 2.

Source: Author's monitoring of events and interpretation in the current framework 
The Economic Freedom Fighters faces the challenge to prove staying power beyond its 2014 election support - $6 \%$ nationally and the strongest opposition party in two of the nine provinces.

In the 1999-2014 period it was mainly the ID and Cope, along with the batch of minor floor-crossing parties, which fed into party alliances (inclusive of minor splitting and realignment processes). Most of the alliances aimed at constituting an effective opposition, chipping away at the ANC's continuous majorities. The issues they battled with ranged from the question of participation in the parliamentary system to ideological purity and racial consciousness.

\section{Table 4}

\section{Historical trajectory of party alliances and coalitions, counter-posed with party splits and split-offs}

\begin{tabular}{|c|c|c|c|c|}
\hline Date & Parties & $\begin{array}{l}\text { Subsequent } \\
\text { political } \\
\text { formation }\end{array}$ & Generic reason & Durability \\
\hline 1994 & ANC, NP and IFP & $\begin{array}{l}\text { Coalition } \\
\text { government with } \\
\text { dominant ANC in } \\
\text { command }\end{array}$ & $\begin{array}{l}\text { Preceding } \\
\text { conflict and } \\
\text { constitutional } \\
\text { settlement }\end{array}$ & $\begin{array}{l}\text { Two years and then } \\
\text { gradually faded } \\
\text { out; NP exits; no } \\
\text { attempts at own } \\
\text { transformation; } \\
\text { largely accepted as } \\
\text { sunset measure }\end{array}$ \\
\hline 1997 & \multicolumn{4}{|c|}{ UDM splits off ANC; faction of the NNP splits off NNP } \\
\hline $1997 / 8$ & $\begin{array}{l}\text { ANC and NNP } \\
\text { splits commence } \\
\text { cooperation } \\
\text { towards new } \\
\text { party }\end{array}$ & $\begin{array}{l}\text { Two platforms } \\
\text { merge - the } \\
\text { National } \\
\text { Consultative } \\
\text { Forum (Holomisa } \\
\text { side), and the } \\
\text { New Movement } \\
\text { Process (Meyer } \\
\text { side) }\end{array}$ & $\begin{array}{l}\text { New integrated } \\
\text { non-racial } \\
\text { identity }\end{array}$ & $\begin{array}{l}\text { UDM takes on a } \\
\text { more Eastern Cape, } \\
\text { Africanist identity; } \\
\text { its white component } \\
\text { moves into ANC }\end{array}$ \\
\hline 2000 & DP, NNP and FA & $\begin{array}{l}\text { Party merger } \\
\text { and provincial } \\
\text { government }\end{array}$ & $\begin{array}{l}\text { Imagined } \\
\text { convergence of } \\
\text { ideology and } \\
\text { power }\end{array}$ & $\begin{array}{l}\text { Brief (before ANC } \\
\text { stepped in), until } \\
\text { October } 2001\end{array}$ \\
\hline 2000 & ANC and NNP & $\begin{array}{l}\text { Provincial } \\
\text { government } \\
\text { and phased } \\
\text { incorporation of } \\
\text { NNP }\end{array}$ & $\begin{array}{l}\text { NNP } \\
\text { negotiating } \\
\text { dignifies party } \\
\text { death }\end{array}$ & $\begin{array}{l}\text { Until the following } \\
\text { election, } 2004\end{array}$ \\
\hline 2003 & \multicolumn{4}{|l|}{ ID splits off PAC } \\
\hline
\end{tabular}




\begin{tabular}{|c|c|c|c|c|}
\hline 2003 & $\begin{array}{l}\text { Freedom Front, } \\
\text { Conservative } \\
\text { Party, AUM }\end{array}$ & $\begin{array}{l}\text { New Party: } \\
\text { Freedom Front + }\end{array}$ & $\begin{array}{l}\text { Convergence } \\
\text { of identity and } \\
\text { ideology }\end{array}$ & $\begin{array}{l}\text { Ongoing by 2014, } \\
\text { grows fractionally } \\
\text { in Election } 2014\end{array}$ \\
\hline 2008 & \multicolumn{4}{|c|}{ Cope splits off the ANC } \\
\hline 2009 & $\begin{array}{l}\text { DA, UDM and } \\
\text { Cope }\end{array}$ & $\begin{array}{l}\text { Post-election } \\
\text { loose cooperation }\end{array}$ & $\begin{array}{l}\text { Share some } \\
\text { resources, } \\
\text { campaigns }\end{array}$ & $\begin{array}{l}\text { Very low key, } \\
\text { ephemeral } \\
\text { cooperative } \\
\text { arrangement that } \\
\text { faded }\end{array}$ \\
\hline $2009 / 10$ & DA and ID & $\begin{array}{l}\text { Phased } \\
\text { integration into } \\
\text { DA }\end{array}$ & $\begin{array}{l}\text { Convergence, } \\
\text { ID decline, ID } \\
\text { voters migrate } \\
\text { to DA }\end{array}$ & $\begin{array}{l}\text { Consolidated by } \\
2013\end{array}$ \\
\hline 2011 & $\begin{array}{l}\text { Multiple loose } \\
\text { alliances via local } \\
\text { elections }\end{array}$ & \multicolumn{3}{|c|}{$\begin{array}{l}\text { Local level is not covered in the current analysis, but } \\
\text { a wide range of largely opportunistic alliances to gain } \\
\text { municipal power take hold (see Booysen 2011). }\end{array}$} \\
\hline 2012 & $\begin{array}{l}\text { DA and pre- } \\
\text { Agang SA } \\
\text { (aborted) }\end{array}$ & Did not succeed & $\begin{array}{l}\text { Build effective } \\
\text { opposition }\end{array}$ & $\begin{array}{l}\text { Relationship } \\
\text { increasingly } \\
\text { acrimonious, } \\
\text { Agang SA gets two } \\
\text { National Assembly } \\
\text { seats in Election } \\
2014\end{array}$ \\
\hline 2013 & Sopa and Azapo & $\begin{array}{l}\text { Attempted } \\
\text { merger process } \\
\text { ongoing }\end{array}$ & $\begin{array}{l}\text { Former unity } \\
\text { restored }\end{array}$ & $\begin{array}{l}\text { Azapo participates } \\
\text { in Election 2014, but } \\
\text { fails to win seats; } \\
\text { Sopa cooperates } \\
\text { with EFF in } 2014 \\
\text { candidate lists }\end{array}$ \\
\hline 2013 & \multicolumn{4}{|c|}{ EFF 'splits' off the ANC } \\
\hline \multirow[t]{4}{*}{2014} & Cope & $\begin{array}{l}\text { Migration of } \\
\text { supporters back } \\
\text { to DA and ANC }\end{array}$ & $\begin{array}{l}\text { Voters note the } \\
\text { faction-induced } \\
\text { dissolution }\end{array}$ & - \\
\hline & $\begin{array}{l}\text { UDM and Cope's } \\
\text { Shilowa faction }\end{array}$ & $\begin{array}{l}\text { Absorbed into } \\
\text { UDM }\end{array}$ & $\begin{array}{l}\text { Convenience, } \\
\text { lifeline to } \\
\text { Shilowa } \\
\end{array}$ & Inconsequential \\
\hline & $\begin{array}{l}\text { Cope, IFP, FF+, } \\
\text { ACDP, UCDP }\end{array}$ & $\begin{array}{l}\text { Collective for } \\
\text { Democracy }\end{array}$ & $\begin{array}{l}\text { Minimal, mostly } \\
\text { declining micro- } \\
\text { parties }\end{array}$ & $\begin{array}{l}\text { Nominal rather } \\
\text { than effectual } \\
\text { formation }\end{array}$ \\
\hline & $\begin{array}{l}\text { EFF, Sopa, BCP, } \\
\text { envisaged United } \\
\text { Front }\end{array}$ & $\begin{array}{l}\text { EFF with Sopa, } \\
\text { BCP (same list) } \\
\text { also cooperating } \\
\text { with PAC, Azapo }\end{array}$ & $\begin{array}{l}\text { To constitute } \\
\text { a new left } \\
\text { opposition } \\
\text { formation with } \\
\text { a view to taking } \\
\text { over power } \\
\text { from ANC }\end{array}$ & $\begin{array}{l}\text { EFF and associate } \\
\text { parties cooperate, } \\
\text { potentially linking } \\
\text { to Numsa's United } \\
\text { Front, talks with } \\
\text { WASP, Numsa } \\
\text { praises EFF } \\
\text { election result }\end{array}$ \\
\hline
\end{tabular}

Source: Author's monitoring and interpretation of events 


\section{CAUSES AND MOTIVATING FACTORS IN INITIATING AND MAINTAINING ALLIANCES AND COALITIONS}

South Africa's ' political environment has seen racially and ethnically configured coalitions, ideologically matched or disconnected coalitions, as well as politically opportunistic ones', observes Kadima (2006, p 16). He further explores these contentions about the causes of alliances and coalitions and finds them well sustained. The analysis notes the centrality of gains in or consolidation of political power as a driving force.

In the context of many party political efforts to surmount ethno-racial divisions in South African party politics, and much of the real politik operating in a virtually uncontested (except in revolutionary pretence) ideological terrain, politics often revolves around the ruling party defending the political ground occupied by the previous liberation movement ... and opposition parties set on gnawing into exactly that base. Ideology and identity factors are well used, but are permeable.

The great opposition and alliance battles of South Africa's democratic era, on the national level, have primarily been the attempts of opposition parties to survive and find traction amongst the voters. In the ranks of the micro-opposition parties (those with $2 \%$ or less of national support) many of the coalitions and mergers have equated with party political survival politics (see above), and were only secondarily about building some form of power to challenge the ANC. Some of these struggles play themselves out in provincial politics, in particular in the provinces of the Western Cape and KwaZulu-Natal.

The Western Cape, with its politically marginal character - political control is not cast in stone in the period of analysis, although the DA has been gaining support - was also one of the main sites for alliance formation, and sheds light on the typical causes of alliances in South African politics. One of the significant post-1994 party alliances, between the ANC and the NNP, was triggered by the ANC's desire also to control this minority-character province. It briefly succeeded in doing this, but voter dynamics returned the province to the then opposition. With substantial inter-provincial migration from the Eastern Cape to the Western Cape provincial voter dynamics assure that the questions about continued DA dominance persist. In Gauteng, the ANC majority was set to decline and on the eve of Election 2014 opposition parties briefly contemplated a provincial alliance. The ANC squeezed in on $54 \%$ of the Gauteng vote, obviating possible attempts by ideologically opposing parties such as the DA and EFF to forge some form of alliance.

Beyond these forms of power-mongering as a driving force, the rest of the section explores the role of regime type, leaders simply following migrating 
supporters, electoral system, legislative frameworks, social cleavage, and ideology and policy as causes of South Africa's host of alliances and coalitions.

\section{Impact of the type of political regime}

The type of political regime has been a major factor affecting the formation, or not, of party alliances and coalitions in South Africa's first two decades of democracy. Much of the preceding analysis confirms this point. The ANC, despite notable declines in its support, remains the dominant party (Booysen 2013a; 2014b). This limits the opposition party initiatives to form alliances and coalitions; no amount of manoeuvring will leverage them into majority alliances, except if it is projected as part of a longer-term strategic alliance construction. The DA, for example, since at least its increase in support in 2004 (see Table 2) and certainly since the confirmations of growth in the 2009 and 2014 national and provincial elections, has been positioning itself as the party that will be the vehicle for future electoral challenges to the ANC (see Jolobe 2012).

The fact that South Africa operates a parliamentary political system (see Kadima 2006) in which the dominant party is subject to the extra-parliamentary arms of the ANC contributes to the relatively ineffectual nature of opposition party operations in the National Assembly. The parliamentary ANC is subjugated to both the ANC's executive and policy-making processes and to a second level of political organisation and popular mobilisation where the ANC operates in parallel to the world of party and electoral politics (Booysen 2011, chapter 3).

The ANC in the South African Parliament operates under the strict guidance of the parliamentary caucus and ANC parliamentary counsellors, all directly controlled by the ANC's National Executive Committee (NEC) and the ANC's top six officials. Hence, the ANC in Parliament takes its political instructions and policy directives from the party principals. As is typical of PR electoral systems, their line of accountability is also into the party structures. Whereas this situation is not uncommon, the ANC under President Jacob Zuma (and to some extent before that) has taken full control of the operations of its deployees in legislative institutions.

Hence the parliamentary system is weak and, in effect, shows many of the characteristics of a presidential system, a system that dilutes the effectiveness of Parliament and of provincial representative structures. It also means that opposition party feats in the representative institutions are less notable and unfold in the context of a majority party that uses ongoing legitimacy with the people to circumvent Parliament as the predominant point of connection between party and people. Major opposition party initiatives to engage in supposedly meaningful parliamentary debates frequently amount to toy-telephone conversations. 
There is also the perennial debate about a grand coalition of left forces in South African politics to emerge and rise to formal party status. For this to happen, the ANC would need to split or rapidly decline. Cosatu (or segments of Cosatu) is the most likely source of key drivers of such a process. The SACP has become a tame subsidiary of the ANC and Cosatu, circa 2013-14, was in turmoil, debating whether it was to be confirmed as less challenging on issues of ANC policy and governance. Cosatu general secretary Zwelinzima Vavi, previously a leading light of Cosatu dissent, was suspended due to a workplace sexual misdemeanour. He was reinstated prior to Election 2014 courtesy of an ANC intervention to minimise Cosatu campaigning against it. For the time being, the ANC thus succeeded in stemming Cosatu's potential as a launch pad for future opposition alliances.

\section{Party leaders following their voters into new party arrangements}

One of the basic, if not banal, driving forces in opposition party alliances has been the migration of the weaker of the two parties' supporters to the stronger one; party leaders for their own survival then initiate pre-election alliances with the current hosts of their former supporters. There are several illustrations.

In 1999 many of those who had supported the NP in 1994 failed to vote for the then new NNP. This trend emerged in a series of municipal by-elections in localities like Newlands in Johannesburg and Mogale City on Gauteng's West Rand (Booysen 2011, chapter 8). The migration was confirmed in the 1999 national elections. The NNP was in precipitous decline; attaching itself to the DP (and later to the ANC) was an escape from further annihilation. NNP supporters deserted the NNP for the DA in Election 1999. The NNP leaders, after their brief alliance with the DP/DA (see Kotzé 2001) then liquidated the party and aligned it with the ANC from 2001 onwards.

Another example was the case of the ID in Election 2009. This 2003 floorcrossing party had now reached its support limits. It remained anchored in coloured community support in the Western Cape and the Kimberley area of the Northern Cape. By 2009 its voters were migrating to the DA. It shrank (see Table 2) and negotiations for a gradual merger with the DA commenced. The two parties (and later the one, merged party) formed coalition governments in the Western Cape province, in the Cape Town metropolitan municipality and in a range of other municipalities.

Third, and small-scale, many Cope representatives in the run-up to Election 2014 approached the DA in pre-emptive actions and on sub-alliance-level to help themselves secure places on party lists and dangle the carrot of (black-African) racial identity, sought-after in the DA. Cope's Election 2009 supporters had begun to migrate back either to the DA or to the ANC, which were the two main party 
sources from which the bulk of the 2009 Cope supporters had come (see Greben 2012; Kimmie, Greben \& Booysen 2009). Closer to the election several senior Cope leaders also defected to the ANC; some securing seats in Parliament.

\section{Impact of the electoral system}

Unlike the first-past-the-post (FPTP) system, the list PR makes every vote count. As a result, parties do not necessarily have to enter into pre-election alliances but tend to build post-election alliances in accordance with the number of seats secured by each party. The cases of the coalition governments in KZN from 1994 to 2004 and the Western Cape in 1999 and 2004 illustrate this.

Kadima 2006, pp 52-53

This assertion, closely aligned with the arguments in the previous section, goes hand in hand with the phenomenon of the ANC as an entrenched dominant party. South Africa uses the closed-list PR system with the Droop formula, also known as the highest remainder method. The contesting parties' seat counts are determined according to their share of the vote. As Lodge (2004) points out, '( $t$ )his system means that there is no formal threshold for parliamentary representation'.

In South Africa it has been evident (see section above) that political parties often embark on alliance and coalition initiatives after elections and with a view to the next round of elections. Elections highlight fading party fortunes and leaders then often initiate inter-party cooperation, including gradually building up to new alliances, in order to rescue their own careers, and/or negotiate relatively graceful endings for their parties. The parties do not have direct constituencies to account to and the small parties often have flexible party structures, enabling them to switch with relative ease. The mooted alliance in late 2013 of Cope, FF+, ACDP and UDM was a case in point. It was ineffectual: in Election 2014 (see Table 2) Cope imploded down to one $1 \%$ of the national vote, the already-micro ACDP declined further and the equally small UDM and FF+ both grew minimally off micro-bases.

The parties in a PR system thus do not gain immediate benefits from formal associations through specifically constituted alliances. The mere act of coordinated voting on a particular policy, campaign or governance issue will have as much effect as it would have had had the parties been in a formal coalition. When opposition parties jointly start approaching pivotal vote cut-off points, for example, in the case of blocking a two-thirds parliamentary majority for the ANC, a stronger need for formalised cooperation arises. To illustrate, after Election 2009 the ANC was just short of a two-thirds majority. When the contested issue 
of e-tolls on the Gauteng freeways arose circa 2012-13, the opposition parties jointly required every possible vote to refer the ANC policy to higher courts for further adjudication. At the time, in August-September 2013, Cope (due to internal conflict) was unable to fill a vacancy, and the informal opposition alliance had to secure the support of the one PAC representative in Parliament. The position was occupied by the PAC's then president and sole MP, Letlapa Mphahlele. The opposing PAC factions removed him from his leadership and parliamentary seat. Mphahlele contested his removal, while the informal opposition alliance feared that the internal PAC fallout might have been instigated to prevent them from getting the necessary numbers and forestall the further legal battle and deadlock on e-tolls (see Vecchiatto 2013).

\section{Legal and regulatory context of alliances and coalitions}

The formation of political parties in South Africa is only mildly regulated. They are subject to the general rights and obligations that are integral to the Constitution of South Africa Act No. 108 of 1996 (and before that the Interim Constitution of 1993). Parties enjoy the rights that are granted in terms of freedom of speech, association, organisation and mobilisation, although these rights are subject to not adversely affecting the rights and dignity of fellow South Africans (Constitution of South Africa 2006, article 2).

The Constitution does not specify functions and general rights of political parties (Booysen \& Masterson 2009). The Bill of Rights (article 2, s 19(1) of the Constitution) specifies that every citizen 'is free to make political choices, which includes the right to form a political party; to participate in the activities of, or recruit members for, a political party; and to campaign for a political party or cause'. Every citizen, furthermore, has 'the right to free, fair and regular elections for any legislative body established in terms of the constitution'; the right 'to vote in elections for any legislative body .... and to do so in secret'; and 'to stand for public office, and if elected, to hold office'.

The Electoral Act No 73 of 1998 outlines election procedures and forbids anyone 'to compel or unlawfully persuade any person' to 'register or not to register as a voter', 'to vote or not to vote', 'to support or not to support any registered party or candidate', 'to attend and participate in, or not to attend and participate in, any political meeting, march, demonstration or other political event', and to prevent a party, candidate or official 'from gaining reasonable access to voters, whether in a public or private place'.

The 1996 Constitution is pertinent to coalition formation in that it requires a party, in terms of the PR system, to win an absolute majority in order to have its leader elected president of the country or the premier of a province. In order to 
receive a majority of the votes and govern, coalitions of political parties have been formed when no candidate has secured the minimum level of $50 \%+1 \%$ of support.

The necessity to govern through coalition building has hitherto not emerged at the national level in South Africa. However, in the two provinces of KwaZuluNatal and the Western Cape (also see the last section) it has been required (see Kadima 2006). KwaZulu-Natal went through a relatively long period in which the IFP and ANC had to build coalitions to achieve a majority, until the ANC eclipsed the IFP in 2009 and gained an outright majority of the provincial vote. The ANC moved from $32 \%$ of the provincial vote in 1994, to $39 \%$ in 1995, $47 \%$ in $2004,63 \%$ in 2009 and eventually 65\% in 2014. In the Western Cape the ANC experienced a modest upward trend from 1994 to 2004, peaking at $45 \%$ in 2004, declining to $32 \%$ in 2009 (see Booysen 2011, chapter 6) and rising to $34 \%$ in 2014. The ANC in the Western Cape had won the 1999 elections with a relative majority of $42 \%$, but lost provincial control to the NNP and the DP after the two parties formed the DA and the associated coalition government (see Kadima 2006, p 70). Soon thereafter the ANC regained the province, this time with the help of the NNP, and in the wake of floor crossing.

Floor crossing was thus an important trigger for party political realignment and the evolution of the party system. Legislation was enacted, with the support of most of the opposition parties, to enable the practice. The first of the laws were instituted in 2002. They included the Constitution of the Republic of South Africa Amendment Act No 18 of 2002, the Constitution Second Amendment Act No 21 of 2002, the Local Government Municipal Structures Amendment Act No 20 of 2002, and the Loss or Retention of Membership of National and Provincial Legislatures Act No 22 of 2002 (see Booysen 2011, chapter 7).

In response to objections the Cape High Court halted the promulgation of the legislation and deferred it to the Constitutional Court of South Africa, which ruled that floor crossing was consistent with the founding values of South Africa's Constitution and its Bill of Rights and that defection in a PR system was compatible with democracy. It noted that unhappiness in terms of the principles of proportionality 'should be dealt with in the next election' (Constitutional Court 2002). While the court upheld floor crossing at local government level it also upheld the UDM-IFP challenge to the Membership Act (intended to enable floor crossing at the national level) on the technical grounds that the legislation 'impermissibly amended the Constitution by means of ordinary legislation rather than a constitutional amendment' (see Devenish 2003). In response to this ruling Parliament passed the Constitutional Amendment Act 2003. A series of window periods followed in which floor crossing first flourished and then waned.

These measures enabled an elected representative in Parliament, the provincial legislature or a local council to become a member of another party 
while retaining membership of the legislative body. It also became possible for an existing political party to merge with another party or to subdivide into more than one party while allowing an MP affected by such changes to retain membership. For floor-crossing legislation to apply, the number of members leaving the original party had to represent not less than $10 \%$ of the total number of seats held by the original party in that legislature (see Kadima 2006, p 71). The effect was that the larger parties, and especially the ANC in Parliament and the provinces, remained largely unaffected. The ANC at its Polokwane conference deliberated floor crossing, but vacillated. The ANC as government took over and subsequently passed prohibitive legislation. The president finally signed off on the legislation outlawing floor crossing in early 2009.

\section{Social cleavage as a contributing factor}

Ethnicity, race and culture have shaped South Africa's political history - and continue to do so in the present in alliance formation. South Africa's smaller political parties often have relatively exclusive racial-cultural profiles and the bigger ones have their job cut out in attempting to cross the barriers imposed by race, ethnicity and culture.

Both the ANC and the DA are known to have multiracial memberships. The DA claims to be the most multiracial of South Africa's political parties (www.da.org.za 2013). Yet, despite by 2014 claiming to have more black than white members, it carries the image of a predominantly white and upper class party. Research revealed a view that, as the ANC would also like the majority of South Africans to believe, should the DA come to power it will bring back apartheid (Booysen 2013b). The ANC, in turn, has suffered serial problems in capturing minority group voters from coloured, Indian and white backgrounds (see Greben 2012). Some of its previous breakthroughs have also been reversed.

The role of race-ethnicity in party alliances, in both election and betweenelection periods, is illustrated in Table 3. For example, the ID followed its largely coloured middle- and working-class voters who had already migrated to the DA, after their brief stint with the ID (see section above). Afrikaner nationalist parties banded together in the coalition-merger of the FF, CP and AUM (to form the FF+). When the NNP had itself been incorporated into the ANC, the bulk of NP supporters and leaders had already moved to the DA. Ironically, it was the more nationalist-conservative grouping in the NNP, and those with the highest power ambitions, which remained for the merger with the ANC.

At the opposite end of the continuum, several coalitions had as an important motivating factor the aspiration of the parties to bridge the social cleavages typical of South African society. The GNU formation was an obvious case in point (see 
Kadima 2006). Thereafter, upon Bantu Holomisa's fallout with the ANC and Roelf Meyer's with the NNP, these two groupings entered the alliance fray with the vision of 'uniting citizens in their South Africanness' (www.udm.org.za 2013). The ID and DA coalition helped guarantee the DA a notable coloured constituency (see section above). Cope, in its fleeting heyday, brought together both the ANC splitoff and a substantial block of followers from across South Africa's racial spectrum.

The PR system's low threshold for representation enhances the inclusion of a range of minority parties (Mottiar 2003, p 7). Many of the small parties have distinct racial and ideological characters and would have been excluded in a FPTP system.

\section{Ideology and policy as a thrust for alliance and coalition formation}

Post-apartheid South Africa has turned into an ideological melting pot and a battlefield of ideological compromises, two trends that affect the potential for alliances and coalitions. The socialist thrust of the ANC's Freedom Charter of 1955, which is, to this day, a guiding document for South Africa's ruling party, was moderately interpreted in democratic South Africa. Soon after his release Nelson Mandela made some fundamental economic policy reversals (compared to the ANC's assumed more radical thrust) (see Booysen 2011, chapter 2). This change was further confirmed in the 1995 adoption of the Growth, Employment and Redistribution (Gear) strategy, which largely replaced the Reconstruction and Development Plan (RDP), originally drafted by Cosatu and which came to embody the thrust of the ANC's 1994 election campaign. The trend continued in the ANC's adoption of the National Development Plan (NDP). In addition, the SACP had retained little of its expected socialist thrust.

This compromise and moderation, which removed much of the ideological contest from South African politics, also meant that some alliances and party amalgamations became more feasible. For example, in the mid-1990s the NNP still feared the communist element in the ANC. By the time it had to realign to rescue itself, communism was the last thing on its mind, apart from the fact that socialism had effectively been abandoned by the ANC and the Tripartite Alliance. It mostly remained alive in rhetoric and broad interpretation of their own actions as government. On the subject of labour brokers, for example, the ANC was morally obliged to be sympathetic to Cosatu's anti-brokering line, yet some ANC leaders were involved in the practice.

It was equally evident, in the times of both Tony Leon and Helen Zille as leaders of the DP /DA, that the party was adopting some ideas that were associated with the ANC yet might help the DA win support. Differentiation nevertheless remained clear in the ANC's greater emphasis on state responsibility and 
involvement in the economy, and on specifics such as its vacillation on a youth wage subsidy and a ban on labour brokers. Despite some clear differentiation, the major mobilisational thrust for the DA became its crusade against state corruption. On this theme the DA found resonance with many of the other smaller opposition parties, but this was still insufficient to drive the type of overriding opposition party alliance seen in several other African countries.

The often envisioned great ANC split and realignment to form a viable and left-oriented alternative continued to falter and minor new left or approximately left political parties are flying solo. These include the Workers and Socialist Party (WASP) and the Democratic Left Front (DLF). By mid-2014 the potential for a new left opposition alliance was growing, given both the EFF's project for the alignment of left-opposition forces and Numsa's repeated indications post-Election 2014 that it will proceed with forming a workers' party.

\section{CONSEQUENCES OF ALLIANCES AND COALITIONS}

Given that South Africa since 1994 has only seen a handful of significant party alliances and coalitions, which evolved into governance relations, it follows that the impact and consequences have mostly not been far-reaching. However, these two types of formations have played notable roles in the evolution of the party system; they have contributed to governability, to some extent to social cohesion and democratic consolidation and had further potential to bring an ideological realignment. The rest of this section highlights these effects.

\section{Governability}

The main governability feat at national level remains the GNU arrangement of 1994. In this time of transition from struggle and instability to democracy, the co-governance arrangement established the inclusivity of the main actors and enhanced rapid acceptance of the emerging democratic order.

On the sub-national level it was only in the case of KwaZulu-Natal prior to the ANC in 2009 asserting an outright provincial majority that governability was evident as a concrete outcome of the coalition in the province between the ANC and the IFP. In the period between 1994 and 2009 the two parties were in a forced coalition government - neither had been able to win an outright majority and there was the likelihood of a resurgence of the pre-1994 violence should one party dominate the provincial government.

The ANC and the IFP remained in electoral competition throughout this period with the ANC gradually encroaching on the IFP's electoral territory. Some parts of the province remained no-go areas for the ANC up to the run-up 
to Election 2009. The IFP was further eroded when the NFP split off at the time of the 2011 local elections. In the aftermath of these elections the ANC and the NFP entered into coalition governments in several municipalities in the province-but with a notable backlash from some NFP voters who continued to feel closer to the IFP than to the ANC.

Coalition government between the ANC and the NNP in the Western Cape advanced the ANC's determination to gain dominance in this province, a territory it projected as still in need of liberation from the forces of the status quo ante. The Western Cape, unlike KwaZulu-Natal, had not experienced an era of virtual civil war and had no problems of governability. The issue was merely which party would be the dominant governing party, with coalition formation as a secondary issue.

\section{Social cohesion}

Party alliances and coalitions in democratic South Africa have, on occasion, attempted to, and modestly if fleetingly succeeded in, building some social cohesion. The UDM - combining, in the main, split-offs from the ANC and the NNP - was one such effort. Although the coalition and the subsequent incorporation of the NNP into the ANC amounted to the as-graceful-as-possible disbandment of the NNP, the party's leadership presented it as a major act of sociopolitical advancement. In the words of Van Schalkwyk at the time of the event (2004; also see Quintal 2004): 'The NNP welcomes president [former President] Thabo Mbeki's emphasis on the need for all South Africans to be co-builders of the new South Africa' and 'The NNP chooses to put the national interests of all South Africans above narrow party political interests and to be part of the solution in our country.'

Cope, in as much as it was constituted through support from the two main feed-parties, the ANC and DA, also delivered evidence of some coming together of racial streams in South African politics. The DA and the ID, in combining an at-the-time still substantially white party (the DA) and a party that had, by voter choice, become largely a coloured-support party (the ID), could be seen as also contributing to making the DA more racially inclusive. The IFP has reasonably consistently over time retained white South African support and leadership, albeit in small and decreasing numbers.

These modest developments may be seen in the context of the fact that the ANC has continuously experienced challenges in expanding into-or retaining its support where breakthroughs had happened - racial minority communities. As stated above, the DA from 2011 onwards claimed to have become the most racially balanced party in the country. The ACDP, with 'Christian' as its predominant 
profile, remains micro, but has some non-racial presence. Other political parties, and predominantly the micro-parties such as the PAC, APC, Azapo and the NFP, along with the $\mathrm{FF}+$ and $\mathrm{MF}$, largely retained their racially exclusive character.

\section{Party system and democratic consolidation}

The inter-party alliances and coalitions of democratic South Africa, and particularly the grander ones of the decade 1994-2004, involving the ANC, NNP and DA, reshaped the party political landscape. Primarily, the developments helped mop up the remnants of the dying NNP, whose 20\% support in Election 1994 was fast being disseminated across a range of recipient parties. The substantial chunk that went to the DP-DA helped project this party as the biggest challenger (albeit lagging by a wide margin) to the ANC in the second decade of democracy. By mid-2014 indicators, it provided the trigger for South Africa's movement in the direction of a two-party system. Nevertheless, the EFF and the budding Numsarelated workers' party (especially if endorsed by Cosatu; see Forum for Public Dialogue 2013) could still challenge this two-party configuration.

Given the persistent high levels of inter-party activity among the small and micro opposition parties, a further trend also needs to be recognised: the coexistence of this emerging (but potentially challenged by the EFF and / or workers' party) two-party system and the world of much inter-party activity amongst the small parties.

By mid-2014 there was still little definitive evidence of new party political projects emerging. The experience with Cope, including its dismal fate in Election 2014, limited the appetite for splits and breaks from the predominant party except in the case of the acrimonious fall-out between the ANC and the former ANCYL, now the EFF. With increased turmoil in the Tripartite Alliance, in the form of disunity within Cosatu, the possibility of this powerful formation being the source of future realignment also remains on the horizon. 


\section{- REFERENCES}

African National Congress (ANC). 2013. Available at: www.anc.org.za multiple windows.

Booysen, S. 2006. 'The will of the parties versus the will of the people? Defections, Elections and Alliances in South Africa'. Party Politics 126, December.

Booysen, S. 2010. 'Party opposition perpetually on the verge of promise - South Africa's Election 2009'. Journal of African Elections 9(1).

Booysen, S (ed). 2012. Local elections in South Africa: Parties, people, politics. Stellenbosch: Sun Press with Konrad Adenhauer Stiftung.

Booysen, S. 2013a. 'The ANC circa 2013: Colossus in decline?'. In J Daniel, P Naidoo, D Pillay \& R Southall (eds). New South Africa Review 3: The second phase tragedy or farce? Johannesburg: Witwatersrand University Press.

Booysen, S. 2013b. Twenty years of South African democracy: Citizen views of governance, human rights and the political system. Community survey report, report for Freedom House, Washington, DC and Johannesburg, December, 25 nationally distributed focus group discussions.

Booysen, S. 2014a. 'Electorate reconfigures multipartyism'. The Sunday Independent, 11 May. Available at: www.iol.co.za/sundayindependent/electoratereconfigures-multipartyism-1.1686374\#.U38RkiggU24.

Booysen, S. 2014b. 'Election 2014'. Keynote address, Transformation Lecture Series', University of Johannesburg, 16 May 2014.

Booysen, S \& G Masterson. 2009. 'South Africa'. In D Kadima \& S Booysen (eds). Compendium of Elections in Southern Africa, 1989-2009: 20 years of multiparty democracy. Johannesburg: Electoral Institute of Southern Africa (EISA).

Constitutional Court of South Africa, 4 October 2002, Case No. CCT 23/02. Available at: www.concourt.gov.za/files/udm

Economic Freedom Fighters (EFF). 2014. Interview, Johannesburg, 17 May.

Democratic Alliance (DA). 2013. Available at: www.da.org.za multiple windows.

Devenish, G. 2003. 'Political musical chairs - The saga of floor crossing and the Constitution'. Seminar paper, Howard College, University of Natal, Durban, 5 April.

Forum for Public Dialogue. 2012 released 2013. Survey of Cosatu shop stewards. Johannesburg.

Greben, J. 2012. 'Voter movements between elections - linking the 2011 and preceding election results using cluster trend matrices'. In S Booysen (ed). Local elections in South Africa: Parties, people, politics. Stellenbosch: Sun Press with Konrad Adenhauer Stiftung.

Jolobe, Z. 2012, 'A party for all the people? The DA and the 2011 elections'. In S Booysen (ed). Local elections in South Africa: Parties, people, politics. Stellenbosch: Sun Press with Konrad Adenhauer Stiftung. 
Joubert, J-J. 2013. 'No deal: How Mamphela Ramphele dumped Helen Zille'. City Press 19 May. Available at: www.citypress.co.za/politics/no-deal/.

Kadima, D. 2006. 'The study of party coalitions in Africa: Importance, scope, theory and research methodology'. In D Kadima (ed). The Politics of Party Coalitions in Africa, Johannesburg: Konrad Adenauer Stiftung and EISA.

Kimmie, Z, J Greben \& S Booysen. 2010. 'A review of the 2009 South African election'. Politeia 291, Special edition: Elections in Africa.

Kotzé, H. 2001. 'The potential constituency of the DA: What dowries do the DP and NNP bring to the marriage?' In Konrad Adenhauer Stiftung. Opposition in South Africa's new democracy. Johannesburg: KAS.

Lodge, T. 2004. EISA Election Update - South Africa 2004. Update No 1. Johannesburg: EISA.

Mabasa, L. 2013. Interview, South African Broadcasting Corporation SABC, SAFM, 12 June.

Mbeki, T. 2004. 'Letter from the president'. ANC Today 4(32), 13-19 August.

Mottiar, S. 2003. 'Evidence strongly favours PR'. Synopsis 7(1). Centre for Policy Studies.

Munusamy, R. 2013. 'Rupture: New workers' party likely to emerge from Numsa special congress'. Daily Maverick, 29 November. Available at: www. dailymaverick.co.za/article/2013-11-29-rupture-new-workers-party-likelyto-emerge-from-numsa-special-congress / \#.UqBvo-IgXdV

Ndaba, B. 2013. 'Impasse thwarts Azapo, Sopa merger'. The Star, 5 December. Available at: www.iol.co.za/news/politics/impasse-thwarts-azapo-sopamerger-1.1617223\#.UqYlbOIgU24

Quintal, A. 2004. 'I'm at home with ANC views - Van Schalkwyk'. The Star, 17 August.

Schulz-Herzenberg, C. 2005. 'The New National Party: The end of the road'. In J Piombo \& L Nijzink (eds). Electoral Politics in South Africa: Assessing the First Democratic Decade. New York: Palgrave Macmillan.

Seale, L. 2013. 'Parties join forces to rein in the ANC'. The Star, 6 December 2013.

Sitter, N. 2002. 'Cleavages, party strategy and party system change in Europe, East and West'. Perspectives on European Politics and Society 3(3).

United Democratic Movement (UDM). 2013. Available at: www.udm.org.za multiple windows.

Van Schalkwyk, M. 2004. 'An NNP role in ANC delivery'. ThisDay, 29 January.

Vecchiatto, P. 2013. 'Lone PAC MP seeks interdict to stop assembly's speaker replacing him'. Business Day, 26 July. 